\title{
The first Australasian species of the halophilic pseudoscorpion genus Paraliochthonius (Pseudoscorpiones: Chthoniidae)
}

\author{
Mark S. Harvey \\ Department of Terrestrial Zoology, Western Australian Museum, Locked Bag 49, Welshpool DC, \\ Western Australia 6986, Australia. E-mail: mark.harvey@museum.wa.gov.au. \\ [Research Associate, Division of Invertebrate Zoology, American Museum of Natural History, New York; \\ Research Associate, California Academy of Sciences, San Francisco; Adjunct Professor, School of Animal Biology, \\ University of Western Australia, Crawley, Western Australia 6009, Australia]
}

\begin{abstract}
The widespread halophilic genus Paraliochthonius Beier is recorded from Australasia for the first time, and two new species are recorded: $P$. darwini from tropical northern Australia and P. vachoni from New Caledonia. Paraliochthonius darwini is based upon several adults and a tritonymph, whilst $P$. vachoni is based on a male and a tritonymph. A key to the species of Paraliochthonius is presented, and the taxonomic status of P. insulae Hoff (from Jamaica), P. puertoricensis Muchmore (from Puerto Rico), P. johnstoni (Chamberlin) (from Mexico) and P. mexicanus Muchmore (from Mexico) is assessed, with Paraliochthonius mexicanus being removed from synonymy with $P$. johnstoni and regarded as a distinct species. New terms are proposed for two morphologies of the chelal teeth: diastemodentate for teeth in which a gap is present between adjacent teeth, and juxtadentate for teeth that are abutting each other.
\end{abstract}

Keywords: new species, morphology, taxonomy, Australia, New Caledonia

\section{INTRODUCTION}

Representatives of several pseudoscorpion genera occur exclusively in halophilic habitats. The genera Paraliochthonius Beier, 1956 (Vachon 1960; Beier 1963; Hoff 1963; Muchmore 1972; Lee 1979; Muchmore 1984b; 1994) (Chthoniidae), Garypus L. Koch, 1873 (Wagenaar-Hummelinck 1948; Beier 1963; Lee 1979) (Garypidae), Anagarypus Chamberlin, 1930 (Muchmore 1982) (Garypidae), Halobisium Chamberlin, 1930 (Schulte 1976) (Neobisiidae), Parahya Beier, 1957 (Harvey 1991b; Harvey et al. 2007) (Parahyidae), Nipponogarypus Morikawa, 1955 (Morikawa 1955) (Olpiidae), Nannochelifer Beier, 1967 (Beier 1967c; Harvey 1984) (Cheliferidae), Epactiochernes Muchmore, 1974 (Muchmore 1974) and Mucrochernes Muchmore, 1973 (Muchmore $1973,1984 a)$ are either totally or mostly restricted to sea-shore environments. In addition, individual species of other genera are endemic to intertidal habitats, including species of Chthonius C.L. Koch, 1843 (Hadži 1933) (Chthoniidae), Neobisium Chamberlin, 1930 (Gabbutt 1962, 1965, 1966) (Neobisiidae), Pachyolpium Beier, 1931 (Mahnert and Schuster 1981) (Olpiidae), Serianus Chamberlin, 1930 (Lee 1979) (Garypinidae), Mexachernes Hoff, 1947 (Lee 1979), Parachernes Chamberlin (Muchmore and Alteri 1969) and Pselaphochernes Beier, 1932 (Beier 1956) (Chernetidae). The biological traits of littoral pseudoscorpions have been rarely studied, but notable studies include investigations into the ecology of Neobisium maritimum (Leach, 1817) by Gabbutt $(1962,1966)$ and of Pachyolpium atlanticum Mahnert and Schuster, 1981 by Mahnert and Schuster (1981), and a taxonomic and ecological review of the littoral pseudoscorpions of Baja California, Mexico (Lee 1979).

Recent collecting in intertidal habitats in tropical Australasia has revealed the first populations of the chthoniid genus Paraliochthonius, one on an offshore island near the Kimberley coast in northern Western Australia, another at Darwin, Northern Territory, and a third on the south-western Pacific island of New Caledonia. These species, the first of the genus to be found in the Australasian region, are described in this contribution.

This paper is dedicated to Charles Robert Darwin (1809-1882) in recognition of his contributions to science.

\section{MATERIAL AND METHODS}

The specimens used in this study are lodged in 
the American Museum of Natural History, New York (AMNH), the Museum and Art Gallery of the Northern Territory, Darwin (MAGNT), Muséum d'Histoire Naturelle, Geneva (MHNG), Muséum National d'Histoire Naturelle, Paris (MNHN) and the Western Australian Museum, Perth (WAM). The specimens were studied using temporary slide mounts prepared by immersion of specimens in lactic acid at room temperature for several days, and mounting them on microscope slides with 10 or $12 \mathrm{~mm}$ coverslips supported by small sections of $0.25,0.35$ or $0.50 \mathrm{~mm}$ diameter nylon fishing line. After study the specimens were returned to $75 \%$ ethanol with the dissected portions placed in $12 \times 3 \mathrm{~mm}$ glass genitalia microvials (BioQuip Products, Inc.). Specimens were studied using a Leica MZ-16A dissecting microscope and Olympus BH-2 and Leica DM2500 compound microscope, the latter fitted with interference contrast, and illustrated with the aid of a drawing tube attached to the compound microscopes. Measurements were taken at the highest possible magnification using an ocular graticule. Terminology and mensuration mostly follow Chamberlin (1931), with the exception of the nomenclature of the pedipalps, legs and with some minor modifications to the terminology of the trichobothria (Harvey 1992).

The maps were produced with the computer program ArcMap 9.1 (ESRI, http://www.esri.com) after the relevant locality data were stored in an Access (Microsoft) database.

\section{SYSTEMATICS}

\section{Family Chthoniidae Daday, 1888}

\section{Subfamily Chthoniinae Daday, 1888}

\section{Tribe Tyrannochthoniini Chamberlin, 1962}

Tyrannochthoniini Chamberlin, 1962: 310; Muchmore, 1972: 249; Judson 2007: 57; Harvey 2009 [unpaginated].

\section{Remarks}

First proposed by Chamberlin (1962), the tribe Tyrannochthoniini was recently relimited and diagnosed by Judson (2007) to include six genera, Lagynochthonius Beier, 1951, Maorichthonius Chamberlin, 1925, Paraliochthonius Beier, 1956, Troglochthonius Beier, 1939, Tyrannochthonius Chamberlin, 1929 and Vulcanochthonius Muchmore, 2000, and was thoroughly diagnosed on a series of features including the presence of one or two rows of chemosensory setae on the dorsal surface of the chelal hand, coxal spines only present on coxae II; intercoxal tubercle absent; cuticle of anterior part of carapace very thin; submedian setae of anterior row of carapace lost; lamina superior broad and strongly fimbriate; spinneret of movable finger of chelicera absent or a low tubercle; trichobothria $i b$ and isb situated slightly proximad of middle of chelal palm; sensilla $p 1$ and $p 2$ of movable chelal finger separate (not contiguous); male sternite III elongate medially, with very long notch; epigean species often with strong olive pigmentation. Many of these features are not found exclusively in the Tyrannochthoniini, and occur in other chthonioid pseudoscorpions.

Whilst based on only three species - Tyrannochthonius sp. from Colombia, Lagynochthonius johni (Redikorzev, 1922) from Indonesia, and a species of Paraliochthonius from north-western Australia, named in this paper as $P$. darwini - the molecular analysis by Murienne et al. (2008) found small support for a monophyletic Tyrannochthoniini. The best support for a clade containing these three species was found with a combined analysis using all three genes (CO1, $18 \mathrm{~S}$ and 28S) and with the nuclear genes alone (18S and 28S), but not with the CO1 analysis. In the combined analysis and the analysis using the nuclear genes, the Tyrannochthoniini formed the sister-group to Austrochthonius + Drepanochthonius. Paraliochthonius formed the sister-group to Tyrannochthonius + Lagynochthonius in the combined analysis, but the nuclear genes analysis found Paraliochthonius grouping with Lagynochthonius, with Tyrannochthonius as the sister-group to these.

\section{Chelal teeth morphology}

Chthonioid pseudoscorpions have long been recognized as having differing tooth morphologies, which have been utilized at both specific and generic levels to distinguish between taxa. The terms homodentate, for teeth that are approximately equal sized throughout the length of the tooth row, or heterodentate, for teeth that have alternating sizes throughout the length of the tooth row, have been in use since Chamberlin (1929). There are also differences in the spacing of the chelal teeth, in which the teeth are either widely spaced such that a gap is present between most teeth, or in which the teeth are contiguous such that the teeth abut against each other. The terms 'diastemodentate' (diastema, Greek, space between, interval, and dentatus, Latin, tooth), and 'juxtadentate' (juxta, Greek, near, close, next to, nigh, and dentatus) (Greek and Latin translations from Brown 1956), are here proposed for these variant tooth morphologies.

\section{Genus Paraliochthonius Beier, 1956}

Paraliochthonius Beier, 1956: 58-59; Beier 1963: 76; Hoff 1963: 23; Muchmore 1972: 250-252; Murthy and Ananthakrishnan 1977: 12-13; Muchmore 1984: 121; Harvey 1991: 193; Gardini 1994: 1; 
Harvey 2009 [unpaginated].

Morikawia Chamberlin, 1962: 311-312 (synonymised

by Muchmore 1972: 250).

Stygiochthonius Carabajal Márquez, Garcia Carrillo and Rodríguez Fernández, 2001: 8-9 (synonymised by Judson 2007: 58).

\section{Type species}

Paraliochthonius: Chthonius singularis Menozzi, 1924, by original designation.

Morikawia: Chthonius johnstoni Chamberlin, 1923, by original designation.

Stygiochthonius: Stygiochthonius barrancoi Carabajal Márquez, Garcia Carrillo and Rodríguez Fernández, 2001, by original designation.

\section{Diagnosis}

Species of Paraliochthonius differ from other tyran- nochthoniine chthoniids by the following combination of characters: antero-median seta of carapace not close to epistome (Figures 8, 20); internal margin of chelal hand with at least one, and usually two or more, enlarged spine-like setae which are not situated on greatly enlarged bases (Figures 12, 24).

\section{Remarks}

Eighteen species of Paraliochthonius are currently named (Harvey 2009; Table 1), and evidence is here provided for the recognition of two new species from Australasia, and for removing $P$. mexicanus Muchmore, 1972 from the synonymy of $P$. johnstoni, thus bringing the total to 21 species. A further 16 species have in the past been attributed to Paraliochthonius or its junior synonym Morikawia (Beier 1964, 1965, 1966, 1967a, 1967b, 1969, 1974b, 1974a, 1976, 1977), but these species

Table 1 List of named species of Paraliochthonius, and their distributions and habitat.

\begin{tabular}{|c|c|c|}
\hline Species & Distribution & Habitat \\
\hline \multicolumn{3}{|l|}{ Europe (Figure 4) } \\
\hline $\begin{array}{l}\text { Paraliochthonius barrancoi (Carabajal Márquez, } \\
\text { Garcia Carrillo and Rodríguez Fernández, 2001) }\end{array}$ & Spain (Andalucía) & Troglobitic \\
\hline Paraliochthonius singularis (Menozzi, 1924) & $\begin{array}{l}\text { Croatia, France (mainland), Greece, Italy } \\
\text { (mainland, Sardinia, Sicily), Turkey }\end{array}$ & Epigean \\
\hline \multicolumn{3}{|l|}{ Macaronesian Islands (Figure 5) } \\
\hline Paraliochthonius canariensis Vachon, 1961 & Spain (Canary Islands) & Epigean \\
\hline Paraliochthonius cavalensis Zaragoza, 2004 & Portugal (Madeira) & Troglobitic \\
\hline Paraliochthonius curvidigitatus (Mahnert, 1997) & Spain (Canary Islands) & Troglobitic \\
\hline Paraliochthonius hoestlandti Vachon, 1960 & Portugal (Madeira) & Epigean \\
\hline Paraliochthonius martini Mahnert, 1989 & Spain (Canary Islands) & Troglobitic \\
\hline Paraliochthonius mirus Mahnert, 2002 & Spain (Canary Islands) & Troglobitic \\
\hline Paraliochthonius setiger (Mahnert, 1997) & Spain (Canary Islands) & Troglobitic \\
\hline Paraliochthonius superstes (Mahnert, 1986) & Spain (Canary Islands) & Troglobitic \\
\hline Paraliochthonius tenebrarum Mahnert, 1989 & Spain (Canary Islands) & Troglobitic \\
\hline \multicolumn{3}{|l|}{ Africa (Figure 2) } \\
\hline Paraliochthonius azanius Mahnert, 1986 & Kenya & Epigean \\
\hline \multicolumn{3}{|l|}{ Caribbean, Mexico (Figure 3) } \\
\hline Paraliochthonius carpenteri Muchmore, 1984 & The Bahamas & Epigean \\
\hline Paraliochthonius insulae Hoff, 1963 & Jamaica & Epigean \\
\hline Paraliochthonius johnstoni (Chamberlin, 1923) & Mexico (Baja California Sur) & Epigean \\
\hline Paraliochthonius mexicanus Muchmore, 1972 & Mexico (Jalisco) & Epigean \\
\hline Paraliochthonius puertoricensis Muchmore, 1967 & Puerto Rico & Epigean \\
\hline Paraliochthonius weygoldti Muchmore, 1967 & U.S.A. (Florida) & Epigean \\
\hline \multicolumn{3}{|l|}{ Australasia (Figure 6) } \\
\hline Paraliochthonius darwini, sp. nov. & Australia (Northern Territory, Western Australia) & Epigean \\
\hline Paraliochthonius takashimai (Morikawa, 1958) & Japan & Epigean \\
\hline Paraliochthonius vachoni, sp. nov. & New Caledonia & Epigean \\
\hline
\end{tabular}




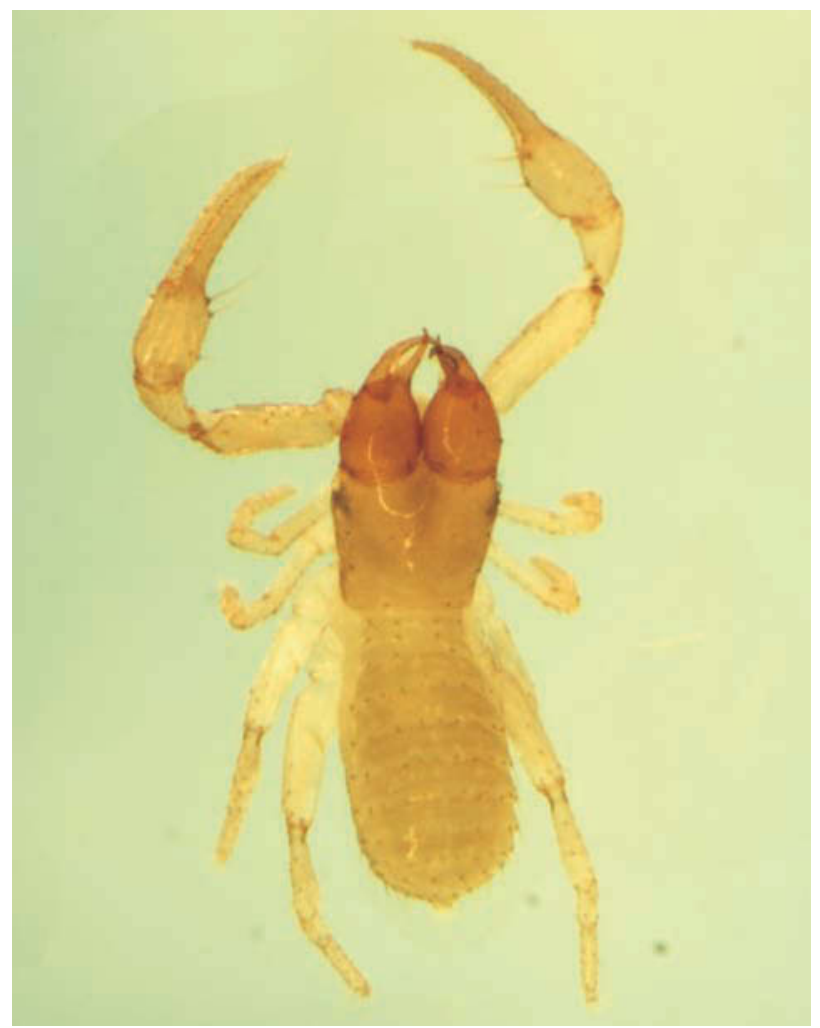

Figure 1 Paraliochthonius darwini, sp. nov., dorsal aspect of paratype male from Berthier Island, Western Australia (WAM T85186).

were subsequently transferred to Tyrannochthonius by Muchmore (1984b), Mahnert (1986) and Harvey (1989). Whilst our knowledge of the species included within Paraliochthonius is now sufficient that it can be readily distinguished from Tyrannochthonius, Lagynochthonius, Vulcanochthonius and Maorichthonius (Muchmore 1972, 1984b, 2000; Judson 2007), it has yet to be adequately distinguished from Troglochthonius which is known from two troglobitic species, the type species $T$. mirabilis Beier, 1939 from Bosnia-Herzegovina and Croatia, and T. doratodactylus Helversen, 1968 from Croatia and Italy (Figure 4). Helversen (1968), Muchmore (1972) and Judson (2007) noted the great resemblance between species of Paraliochthonius and Troglochthonius, with Muchmore (1972) even stating "It would seem preferable to consider Troglochthonius as a polyphyletic group (subgenus) of the genus Paraliochthonius...". This suggestion has not since been adopted and, in any case, Troglochthonius predates Paraliochthonius by 17 years so any form of synonymy would result in the priority of Troglochthonius over Paraliochthonius (Judson 2007). The similarity of the carapacal setation, especially with the anterior-median setae not being situated adjacent to the epistome, and the presence of large spines on the internal margin of the chelal hand suggests that they are very similar, if not synonymous. There appear to be very few characters that distinguish the two genera (Judson 2007). Species of Paraliochthonius have homodentate chelal teeth, whereas species of Troglochthonius have heterodentate teeth. Tooth morphology is variable within other chthoniid genera which comprise both homodentate and heterodentate species, e.g. species of Chthonius (e.g. Beier 1963), Lagynochthonius (e.g. Harvey 1988) and Tyrannochthonius (e.g. Beier 1976; Edward and Harvey 2008). The first four tergites of Paraliochthonius usually have a setal formula of 4 (or very occasionally 3): 4: 4-6: 4-7, whereas both species of Troglochthonius have only 2 setae on each of tergite I-IV. This feature is also highly variable within other chthoniid genera, and is likely to represent a poor feature to define genera. The epistome of Paraliochthonius is usually prominent and triangular, being about twice as long as broad, whereas the epistome of Troglochthonius is either absent (Helversen 1968) or small (Beier 1939). A complete redescription of the type species of Troglochthonius is necessary before any such synonymy can be proposed.

\section{The status of Paraliochthonius mexicanus}

Paraliochthonius mexicanus was described by Muchmore (1972) from a single female collected at La Manzanilla, Bahía Tenacatita $\left(19^{\circ} 17^{\prime} \mathrm{N}\right.$, $\left.104^{\circ} 50^{\prime} \mathrm{W}\right)$, Jalisco, Mexico. It was compared with P. johnstoni, described from a single female from Puerto Escondido, Baja California Sur, Mexico $\left(25^{\circ} 49^{\prime} \mathrm{N}, 111^{\circ} 19^{\prime} \mathrm{W}\right)$ by Chamberlin (1923) and later redescribed by Chamberlin (1962). Muchmore (1972) found $P$. mexicanus to be somewhat larger than $P$. johnstoni; for example, the chela length of the female holotype of P. mexicanus was reported as $1.08 \mathrm{~mm}$ (Muchmore 1972), whereas the female holotype of $P$. johnstoni was given as $0.761 \mathrm{~mm}$ (Chamberlin 1962). He also found differences in the size of the chelal hand, the more slender legs, and differences in the numbers of setae on tergites V-IX: 7: 7: 8: 7: 7 in $P$. mexicanus and 6: 6: 6: 6: 6 in P. johnstoni. Lee (1979) examined the holotype of $P$. johnstoni and found the chaetotaxy of tergites V-IX to be 7: 7: 7: 7: 7, thus diminishing some of the differences between these two species. Additional female specimens of $P$. johnstoni from Baja California were found to have 7-8: 8-10: 7-8: 7-8: 2P(1-2)P2 setae on tergites V-IX, and a chela length of $0.58-0.63 \mathrm{~mm}$. Lee (1979) then synonymized $P$. mexicanus with $P$. johnstoni, claiming that the diagnostic features of $P$. mexicanus simply represented intraspecific variation. Despite the lack of any distinct differences in the tergal setal patterns of $P$. johnstoni and P. mexicanus, there seems to be sufficient evidence that the specimen from Jalisco represents a different species to that from Baja California. The lengths of the female pedipalpal chela, $1.08 \mathrm{~mm}$ in P. mexicanus and $0.58-$ $0.76 \mathrm{~mm}$ in $P$. johnstoni, are sufficiently distinct from each other to suggest species differentiation. This 

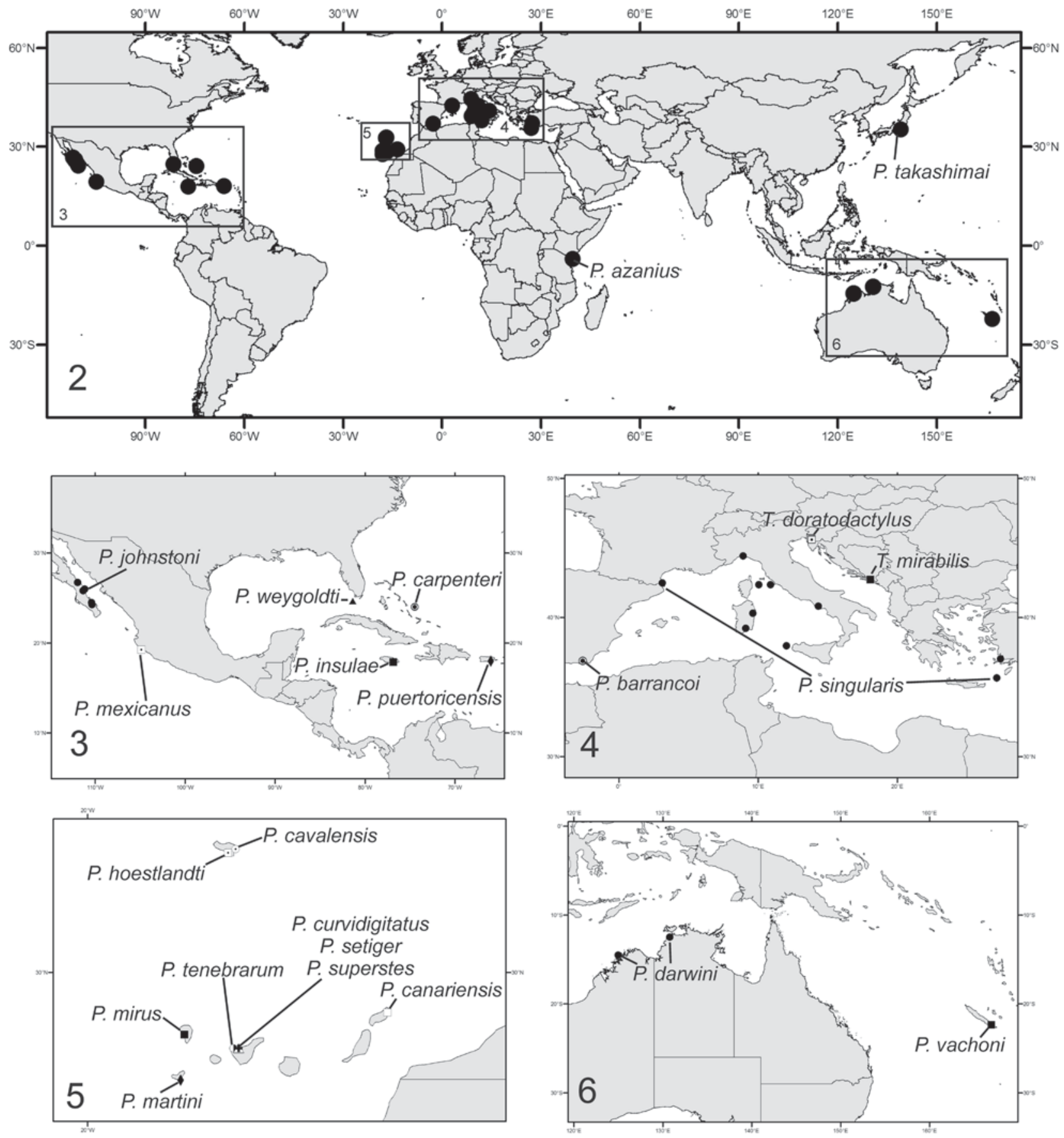

Figures 2-6 Maps showing known distribution of species of Paraliochthonius and Troglochthonius: 2, World map showing P. azanius Mahnert and P. takashimai (Morikawa); 3, Central America showing P. carpenteri Muchmore, $P$. insulae Hoff, P. johnstoni (Chamberlin), P. mexicanus Muchmore, P. puertoricensis Muchmore and P. weygoldti Muchmore; 4, Mediterranean region showing P. barrancoi (Carabajal Márquez, Garcia Carrillo and Rodríguez Fernández) and P. singularis (Menozzi); 5, Macaronesian Islands showing P. canariensis Vachon, $P$. cavalensis Zaragoza, P. curvidigitatus (Mahnert), P. hoestlandti Vachon, P. martini Mahnert, P. mirus Mahnert, P. setiger (Mahnert), P. superstes (Mahnert) and P. tenebrarum Mahnert; 6, Australasia showing Paraliochthonius darwini, sp. nov. and P. vachoni, sp. nov.

size difference is also accordance with differences reported between other species of Paraliochthonius. Therefore, I hereby remove $P$. mexicanus from the synonymy of $P$. johnstoni, and recognize it as a distinct species. Whilst $P$. mexicanus is ostensibly distinct from $P$. johnstoni, it is similar to several other named species of the genus. For example, the chela length of $1.08 \mathrm{~mm}$ is similar to $P$. carpenteri Muchmore, 1984 (ㅇ, 1.125-1.21 mm) from the Bahamas, P. canariensis Vachon, 1961 ( $\widehat{0}, 0.94 \mathrm{~mm})$ from the Canary Islands, P. insulae Hoff, 1963 (,$+ 0.95 \mathrm{~mm}$ ) from Jamaica and P. puertoricensis 
Muchmore, 1967 ( $3,1.07-1.09 \mathrm{~mm}$,, $1.11 \mathrm{~mm})$ from Puerto Rico. However, the presence of three thick spines on the internal margin of the chelal hand in $P$. carpenteri and $P$. canariensis, four thick spines in $P$. insulae and P. puertoricensis, and only two thick spines in $P$. johnstoni and P. mexicanus suggests that $P$. mexicanus is distinct from these taxa.

\section{The status of Paraliochthonius puertoricensis}

Paraliochthonius insulae was described from a single female from Jamaica (Hoff 1963) and $P$. puertoricensis from two males, a female and a tritonymph from Puerto Rico (Muchmore 1967), some $1,000 \mathrm{~km}$ apart. I have examined all four adult specimens (lodged in $\mathrm{AMNH}$ ) and found that in most morphological features $P$. insulae and P. puertoricensis are virtually identical. The arrangement of the chelal spines on the internal margin of the chelal hand is the same, with 2 large spines basally, one near the base of the chelal fingers and another slightly more distally, even though the illustrations provided by Hoff (1963) and Muchmore (1967) do not adequately show these spines. The anterior eye of both species is large, with the posterior eye reduced (Hoff 1963; Muchmore 1967). The dorsum of the chelal hand and fixed chelal finger bears 22 chemosensory setae in all four adults. The only noticeable differences are in the shape of the chelal teeth, where every second tooth is smaller and medially offset in $P$. puertoricensis, and are not smaller or offset in $P$. insulae, and in the slightly larger size of $P$. puertoricensis [e.g. chela length 1.07-1.09 (ठ)), 1.11 (昂) $\mathrm{mm}$ ] than $P$. insulae (e.g. chela length 0.95 (†) $\mathrm{mm}$ ). Further specimens of Paraliochthonius are required from the Caribbean region to assess whether these slight differences are adequate to support the recognition of two separate species.

\section{KEY TO SPECIES OF PARALIOCHTHONIUS}

1. Two pairs of eyes present, with at least the anterior eye represented by a distinct cornea..

Eyes absent, or with only 1 or 2 pairs of faint eye-spots; eyes never corneate. . .14

2. Internal margin of chelal hand with four thickened, anteriorly directed setae.. .3

Internal margin of chelal hand with two or three thickened, anteriorly directed setae................. 4

3. Chela 1.07-1.09 (đ), 1.11 (†) $\mathrm{mm}$ in length; chelal teeth of distal half of fixed finger with every second tooth smaller and offset to the medial side of the finger.

P. puertoricensis

Muchmore, 1967 (Puerto Rico)
Chela 0.95 (†) $\mathrm{mm}$ in length; chelal teeth of distal half of fixed finger all equal sized.

P. insulae Hoff, 1963 (Jamaica)

4. Internal margin of chelal hand with three enlarged, thickened, anteriorly directed setae

Internal margin of chelal hand with two enlarged, thickened, anteriorly directed setae

5. Trichobothrium $s b$ midway between $b$ (formerly st) and st (formerly b); trichobothrium ist slightly basal to level of $e b$ and $e s b$

P. azanius Mahnert, 1986 (Kenya)

Trichobothrium $s b$ closer to $b$ (formerly $s t$ ) than to st (formerly $b$ ); trichobothrium ist level with, or slightly distal to level of $e b$ and $e s b \ldots 6$

6. The three thickened, anteriorly directed chelal setae equidistant from one another.... . .7

The three thickened, anteriorly directed chelal setae with basal seta slightly further separated from others. . .8

7. Posterior pair of eyes reduced to eye-spots

$$
\text { ..P. singularis (Menozzi, 1924) }
$$

(Mediterranean region)

Posterior pair of eyes corneate.........P. carpenteri Muchmore, 1984 (The Bahamas)

8. Smaller species, e.g. movable chelal finger length

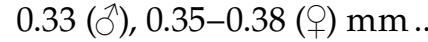
......... P. weygoldti Muchmore, 1967 (Florida)

Larger species, e.g. movable chelal finger length greater than $0.45 \mathrm{~mm}$..

9. Teeth of both cheliceral fingers low and vestigial; smaller species, e.g. movable chelal finger length ca. $0.47 \mathrm{~mm}$.

.. P. darwini sp. nov. (Australia)

Teeth of both cheliceral fingers distinct; larger species, e.g. movable chelal finger length greater than $0.60 \mathrm{~mm}$.. 10

10. Chelal teeth closely spaced, with gaps between teeth smaller than width of tooth base.

P. canariensis Vachon, 1961 (Canary Islands)

Chelal teeth widely spaced, with gaps between teeth greater than width of tooth base .......P. mexicanus Muchmore, 1972 (Mexico)

11. Larger species, e.g. chela length greater than 1.00 $\mathrm{mm}$ and movable chelal finger length greater than $0.80 \mathrm{~mm}$; chelal fingers with $34(\hat{0}$, o $)$ teeth on fixed finger and $36(\hat{0}$, o $)$ teeth on 
movable finger. P. hoestlandti Vachon, 1960 (Madeira)

Smaller species, e.g. chela length less than 0.95 $\mathrm{mm}$ and movable chelal finger length less than $0.75 \mathrm{~mm}$; chelal fingers with fewer than $31(\hat{0}$, o $)$ teeth on fixed finger and fewer than $30(\hat{0}$, o $)$ teeth on movable finger. 12

12. Cheliceral palm with 4 setae [see Remarks on page 000]. ....... P. takashimai (Morikawa, 1958) (Japan)

Cheliceral palm with 5 setae. .13

13. Smaller species, e.g. chela length 0.58-0.76 () $\mathrm{mm}$ in length; teeth of movable chelal finger erect and triangular; anterior setal row of carapace with 6 setae, including 1 pair of anterior-lateral setae. .....P. johnstoni (Chamberlin, 1923) (Mexico)

Larger species, e.g. chela length $0.91\left({ }^{\lambda}\right) \mathrm{mm}$ in length; teeth of movable chelal finger low and retrorse; anterior setal row of carapace with 8 setae, including 2 pairs of anterior-lateral setae (Figure 20)

P. vachoni sp. nov. (New Caledonia)

14. Both chelal fingers strongly curved mesally in dorsal view; base of movable chelal finger with strongly sclerotized apodeme; internal margin of chelal fingers with 1 small thickened seta..

...P. curvidigitatus (Mahnert, 1997) (Canary

Islands)

Chelal fingers not strongly curved mesally in dorsal view; base of movable chelal finger without strongly sclerotized apodeme; internal margin of chelal fingers with 2 or more thickened setae. .15

15. Cheliceral palm with 5 setae. .16

Cheliceral palm with 6 or 7 setae. 20

16. Larger species, e.g. movable chelal finger length greater than $1.30 \mathrm{~mm}$ in length. .. 17

Smaller species, e.g. movable chelal finger length less than $1.20 \mathrm{~mm}$ in length. .19

17. Every second tooth of the fixed chelal finger smaller than other teeth and medially offset 18

Every second tooth of the fixed chelal finger not smaller than other teeth and not medially offset ...... ......P. mirus Mahnert, 2002 (Canary Islands)

18. Larger species, e.g. chela ca. $2.7\left({ }^{\Uparrow}\right), 2.9-3.0$ (ㅇ) $\mathrm{mm}$ in length P. barrancoi (Carabajal

\section{Márquez, Garcia Carrillo and Rodríguez Fernández, 2001) (Spain)}

Smaller species, e.g. chela ca. 2.1-2.3 (đ) ), 2.3-2.6

(P) in length .... ...P. superstes (Mahnert, 1986) (Canary Islands)

19. Larger species, e.g. movable chelal finger length $1.06\left(\delta^{\lambda}\right) \mathrm{mm}$ in length; chelal fingers with 42 $\left({ }^{\lambda}\right)$ teeth on fixed finger and $44\left({ }^{\lambda}\right)$ teeth on movable finger.

...P. martini Mahnert, 1989 (Canary Islands)

Larger species, e.g. movable chelal finger length $0.88\left({ }^{\top}\right) \mathrm{mm}$ in length; chelal fingers with 35 $\left(\delta^{\pi}\right)$ teeth on fixed finger and $37\left(\delta^{3}\right)$ teeth on movable finger....

P. tenebrarum

Mahnert, 1989 (Canary Islands)

20. Chelal teeth homodentate; larger species, e.g. movable chelal finger length 1.41-1.49 () $\mathrm{mm}$ in length; chelal fingers with 44-49 () teeth on fixed finger and 45-47 (P) teeth on movable finger...

..P. setiger (Mahnert, 1997) (Canary Islands)

Chelal teeth heterodentate; smaller species, e.g. movable chelal finger length 0.89-0.99 (i) $\mathrm{mm}$ in length; chelal fingers with 34 (क) teeth on fixed finger and 35 () teeth on movable finger.

......... . cavalensis Zaragoza, 2004 (Madeira)

\section{Paraliochthonius darwini sp. nov. Figures 1, 6-18}

Paraliochthonius sp.: Murienne et al. 2008: 174.

\section{Material examined}

Holotype

Australia: Western Australia: $\widehat{\partial}$, Berthier Island,

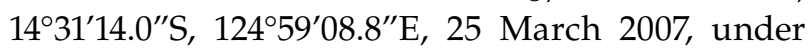
intertidal basaltic rocks, J.M. Waldock and K. Edward (WAM T66747).

\section{Paratypes}

Australia: Western Australia: 3 त, 2 , collected with holotype (WAM T85182, T85183, T85186). Northern Territory: $1 \hat{O}, 4$, Plater Beach, west side of Darwin Harbour, $12^{\circ} 29.25^{\prime} \mathrm{S}, 130^{\circ} 46.55^{\prime} \mathrm{E}, 21$ April 1999, J.K Webber (MAGNT); 1 ¿, 3 , 1 tritonymph, Doctors Gully, Darwin, 12²7'35"S, 130 49'57"E, 10 April 2007, under rocks in intertidal zone, M.S. Harvey (WAM T85184, T85185); 1 $\uparrow, 1$ ㅇ, same data $(\mathrm{MNHN}) ; 1 \hat{\jmath}, 1$, same data (MHNG).

\section{Diagnosis}

Paraliochthonius darwini most closely resembles 

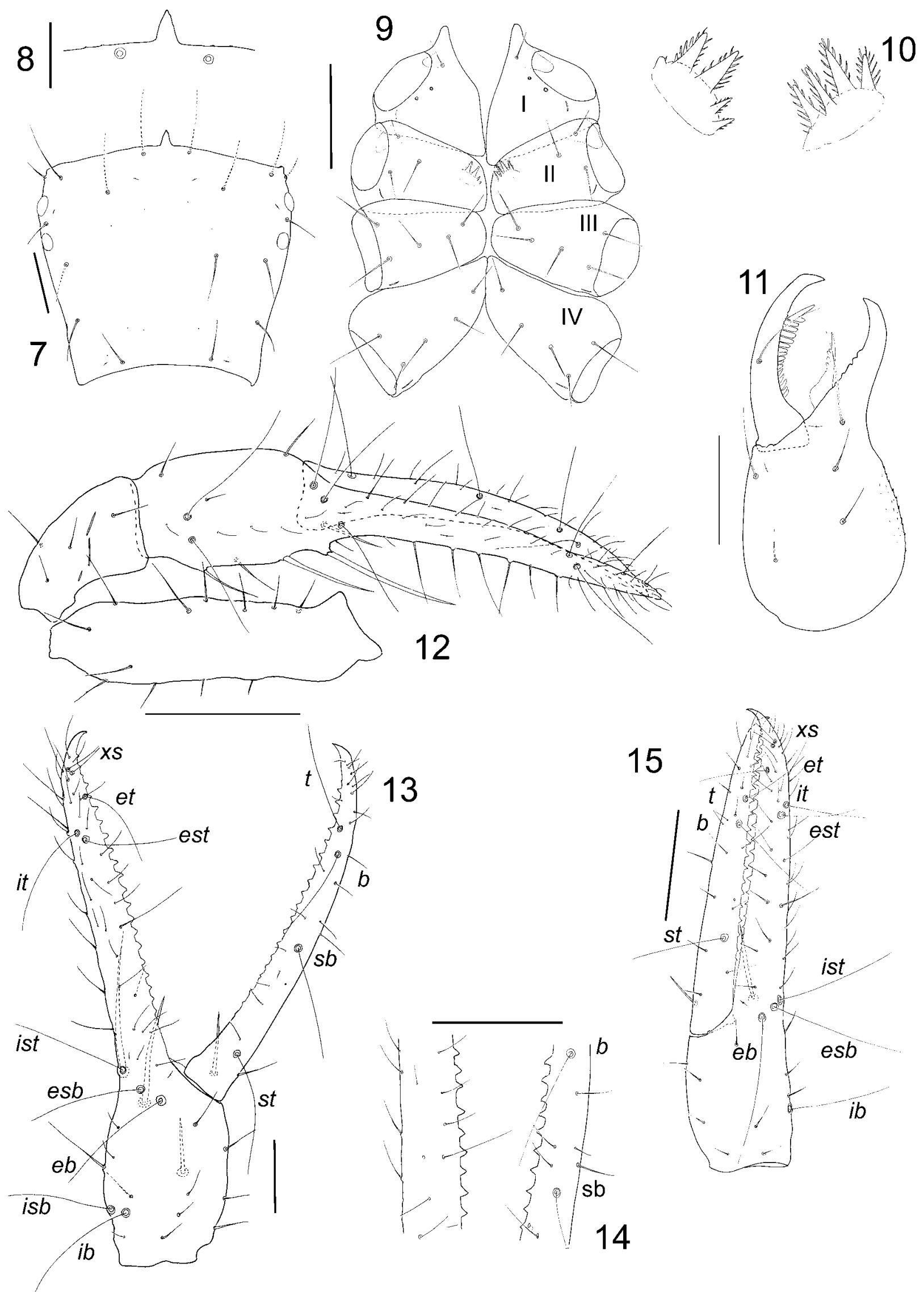

13

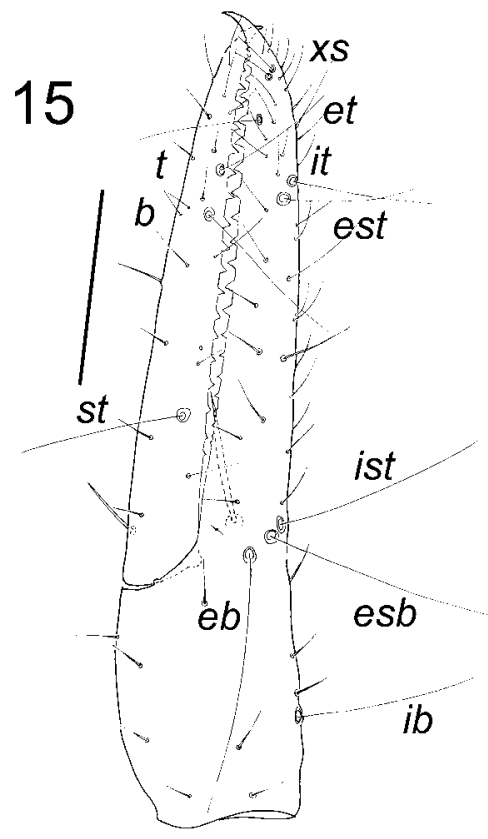

Figures 7-15 Paraliochthonius darwini sp. nov., paratype male (WAM T85182) unless stated otherwise: 7, carapace, dorsal aspect; 8, epistome, dorsal aspect; 9. coxae, ventral aspect; 10, coxal spines, ventral aspect; 11, left chelicera, dorsal aspect; 12, left pedipalp, dorsal aspect; 13, right chela, lateral aspect; 14, detail of chelal teeth; 15, left chela, lateral aspect, paratype tritonymph (WAM T85185). Scale lines $=0.05 \mathrm{~mm}$ (Figure 8), $0.1 \mathrm{~mm}$ (Figures $7,9,11,13-15), 0.2 \mathrm{~mm}(12)$. 
P. canariensis, P. mexicanus and $P$. weygoldti in the possession of two pairs of corneate eyes (Figure 7), three enlarged thickened, anteriorly directed setae on the internal margin of the chelal hand, of which the two distal setae are situated closer to each other than to the basal seta (Figures 12, 13), and trichobothrium $s b$ closer to $b$ (formerly $s t$ ) than to $s t$ (formerly b) (Figure 13). It is larger than P. weygoldti (e.g. movable chelal finger length ca. $0.47 \mathrm{~mm}$ in $P$. darwini and less than $0.40 \mathrm{~mm}$ in $P$. weygoldti), but smaller than $P$. canariensis (e.g. movable chelal finger length $0.61 \mathrm{~mm}$ ) and P. mexicanus $(0.705 \mathrm{~mm})$.

\section{Description}

\section{Adults}

Colour: uniformly light yellow brown (Figure 1).

Chelicera: 5 setae on hand, all setae acuminate (Figure 11); movable finger with 1 medial seta; fixed finger with 3 large teeth followed by 3 small teeth basally, movable finger without obvious teeth but with a row of small hyaline undulations; with 2 dorsal and 1 ventral lyrifissures; galea absent; rallum consisting of 8 blades, anterior blade long and finely denticulate, other blades bipinnate; scaly projections present on lateral edges of hand (Figure 11).

Pedipalp: all setae acuminate (Figure 12); trochanter $1.89\left({ }^{\lambda}\right), 1.71(9)$, femur $3.82\left({ }^{\Uparrow}\right), 3.87(9)$, patella $1.72\left({ }^{\Uparrow}\right), 1.89(+)$, chela $4.86\left({ }^{\Uparrow}\right), 4.85(+)$, hand $0.202\left({ }^{\Uparrow}\right), 1.24$ (ㅇ) $x$ longer than broad; moveable finger $2.31($ ふ), 2.69 (†) x longer than hand, without large basal apodeme. Femur without tactile setae. Patella with three mediodorsal lyrifissures. Fixed chelal finger and hand with 8 trichobothria, movable chelal finger with 4 trichobothria (Figure 13): $i b$ and is $b$ situated close together, sub-medially on dorsum of chelal hand; $e b$, esb and ist forming an oblique row sub-laterally at base of fixed chelal finger; it and est situated sub-distally about one areolar diameter apart, it distal to est; et near tip of fixed finger, close to chelal teeth; $x s$ situated distal to et, each seta shorter than those of other trichobothria; dorsum of chelal hand and fixed finger with a row of microsetae (chemosensory setae); trichobothrium st of movable finger situated sub-basally; $s b$ situated slightly closer to st than to $b ; b$ and $t$ situated sub-distally, $t$ situated at same level as est; $b$ situated basal to est. Internal margin of hand with 2 large and 1 smaller acuminate spine-like setae, 1 situated at level of $e s b$, the second slightly posterior, and the third, which is smallest, situated medially on hand; inner margin of movable chelal finger with three small spines, largest basally. Single small sensillum situated proximal to $s b$ (Figure 14). Venom apparatus absent. Chelal teeth homodentate and diastemodentate: fixed finger with $21\left({ }^{\Uparrow}\right), 22$ (ㅇ) acute teeth; movable finger with $23\left({ }^{\Uparrow}\right), 24(+)$ acute, strongly diastemodentate; accessory teeth absent (Figure 14). External and internal chelal condyles small and rounded.

Cephalothorax: carapace $0.85\left(\zeta^{\Uparrow}\right), 0.82(+)$ x longer than broad; lateral margins constricted posteriorly; with four small corneate eyes (Figure 7); triangular epistome present, slightly longer than wide (Figure 8 ); with 18 or, occasionally 17, setae arranged 6: 4: 3-4: 2: 2; with very shallow furrow situated near posterior margin; the pre-ocular seta about 50\% length of other setae in anterior row; antero-median seta not situated at base of epistome (Figure 7); with 3 pairs of small lyrifissures, first and second pairs situated in ocular row, third pair situated lateral to setae of posterior row. Chaetotaxy of coxae: 2+3: 3: 3: 5: 5 (Figure 9); manducatory process with 2 acuminate distal setae, anterior seta about 2/3 length of medial seta; pedipalpal coxa without dorsal setae; coxae II with 4 coxal spines on each side, set in oblique row (Figure 10), each spine with multiple incisions extending to base of spine; intercoxal tubercle absent (Figure 9); without sub-oral seta; coxa I with large, rounded apical projection (Figure 9); setae on coxa I situated near trochanteral foramen (Figure 9).

Abdomen: pleural membrane papillostriate. Tergites and sternites undivided; setae uniseriate and acuminate. Tergal chaetotaxy: holotype $\hat{\sigma}, 4$ : 4: 4: 10: 10: 11: 11: 11: 10: 4: 4: 0; paratype क, 4: 4: 4: 10: 12: 11: 12: 11: 10: 4: T2T: 0. Sternal chaetotaxy: holotype $\hat{\delta}, 10:$ (3) 24 [4+4] (3): (3) 6 (3): 12: 12: 12: 13: 13: 9: -: 2; paratype +, 5: (3) 7 (3): (3) 6 (3): 12: 14: 15: 14: 14: 11: -: 2.

Genitalia: male genitalia with small ejaculatory atrium, lateral apodeme meeting in midline (Figure 17); glandular genital setae in 2 parallel rows of 4; sternite III with V-shaped opening (Figure 16). Female genitalia with incomplete lateral apodeme frame, lateral diverticulum densely cribrate (Figure 18).

Legs: femora I and II longer than patellae I and II; femora I and II with 1 small transverse lyrifissure situated sub-basally; femur + patella of leg IV 2.98 (ð), 2.67 (ㅇ) x longer than broad; tibiae III and IV with 1 medial tactile seta; metatarsi III and IV with 2 seta longer than others; heterotarsate; subterminal tarsal setae not distally serrate; arolium same length as claws, not divided; claws simple.

Dimensions ( $\mathrm{mm}$ ): male holotype WAM T66747: Body length ca. 1.31. Pedipalps: trochanter $0.200 / 0.106$, femur 0.416/0.109, patella 0.205/0.119, chela $0.685 / 0.141$, hand length 0.202 , movable finger length 0.466. Chelicera 0.366/0.179, movable finger length 0.200. Carapace 0.339/0.397. Anterior eye diameter 0.035 , posterior eye diameter 0.027 . Leg I: femur 0.494/0.048, patella 0.115/0.051, tibia 0.130/0.044, tarsus 0.250/0.037. Leg IV: femur + 

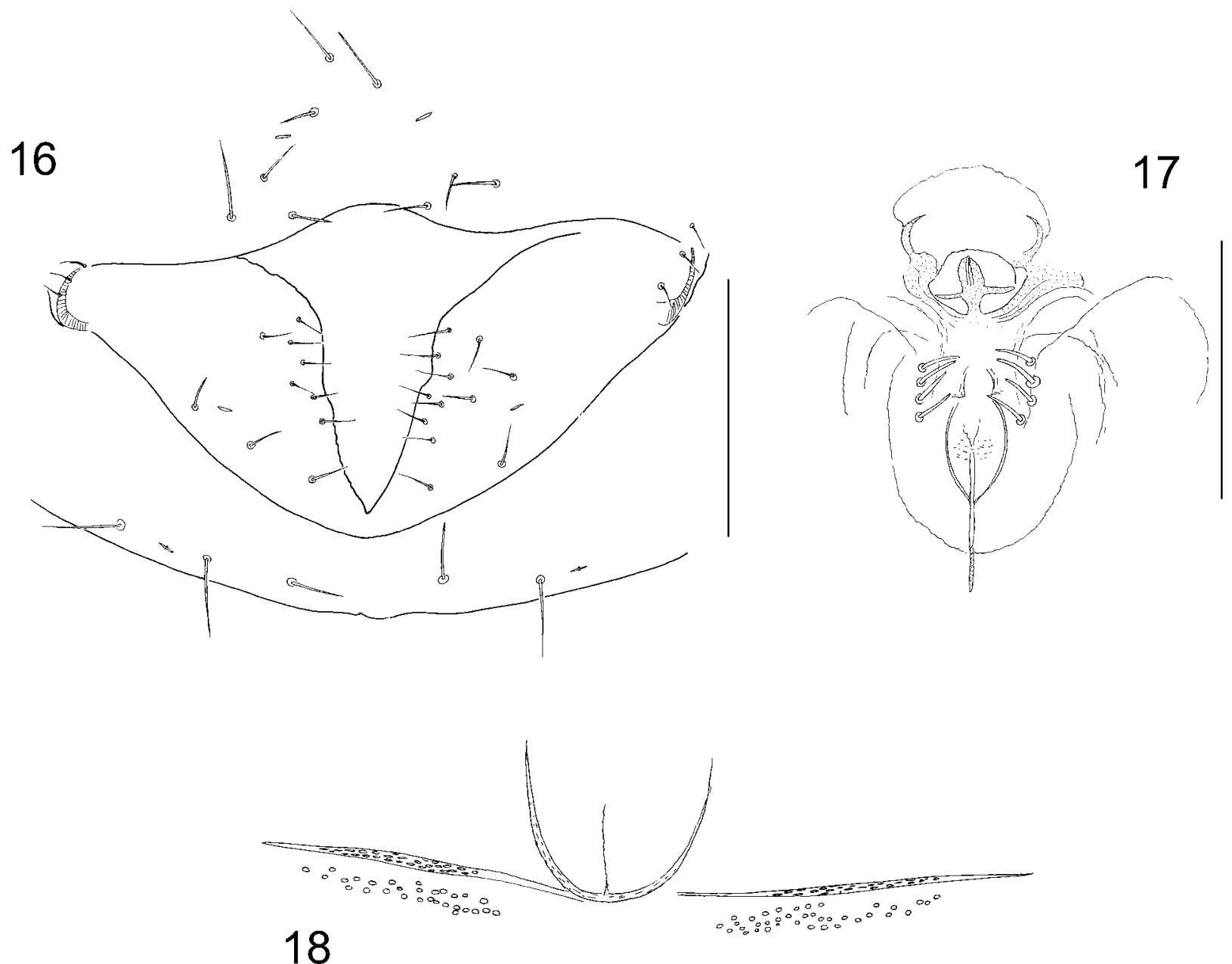

Figures 16-18 Paraliochthonius darwini sp. nov.: 16, sternites II and III, ventral aspect, paratype male (WAM T85182); 17, genitalia, ventral aspect, paratype male (WAM T85182); 18, genitalia, ventral aspect, paratype female (WAM T85183). Scale lines = $0.1 \mathrm{~mm}$ (Figures. 16, 17), $0.2 \mathrm{~mm}$ (Figure 18).

patella $0.429 / 0.144$, tibia $0.273 / 0.068$, metatarsus $0.114 / 0.050$, tarsus $0.248 / 0.040$.

Dimensions $(\mathrm{mm})$ : female paratype WAM T85183: Body length 1.50. Pedipalps: trochanter $0.197 / 0.115$, femur $0.426 / 0.110$, patella $0.220 / 0.116$, chela $0.688 / 0.142$, hand length 0.176 , movable finger length 0.474 . Chelicera $0.378 / 0.190$, movable finger length 0.206. Carapace 0.352/0.428. Anterior eye diameter 0.032 , posterior eye diameter 0.035 . Leg I: femur $0.311 / 0.059$, patella $0.116 / 0.052$, tibia $0.136 / 0.045$, tarsus $0.248 / 0.037$. Leg IV: femur + patella $0.379 / 0.142$, tibia $0.278 / 0.071$, metatarsus $0.112 / 0.055$, tarsus $0.250 / 0.040$.

\section{Tritonymph}

Colour: generally pale yellow orange, chelicera slightly darker.

Chelicera: 5 setae on hand, all setae acuminate; movable finger with 1 medial seta; galea represented by a slight bulge near sub-distal end of movable finger.
Pedipalp: femur 3.58, patella 1.73, chela 4.71, hand $1.39 \mathrm{x}$ longer than broad; moveable finger $2.26 \mathrm{x}$ longer than hand, without large basal apodeme. Fixed chelal finger and hand with 7 trichobothria, movable chelal finger with 3 trichobothria (Figure 15): $i s b$ and $s b$ absent, $i b$ situated sub-medially on dorso-lateral section of chelal hand; $e b, e s b$ and ist situated close together in an oblique row, sublaterally at base of chelal fingers; it situated slightly distal to est, about one areolar diameter apart; et situated basal to $x_{S}$, close to chelal teeth; $x_{S}$ situated sub-distally, each seta shorter than those of other trichobothria; row of microsetae (chemosensory setae) present on dorsum of hand and fixed finger; trichobothrium st of movable finger situated subbasally; $b$ situated sub-distally near $t$, ca. 4 areolar diameters apart; $t$ at level of $i t$. Hand with 2 large, medial acuminate spine-like setae at level of $e b$ and esb. Venom apparatus absent. Chelal teeth homodentate and diastemodentate: fixed finger with 22 large, well-spaced, erect teeth; movable 
finger with 18 well-spaced, slightly retrorse teeth; accessory teeth absent.

Cephalothorax: carapace $0.72 \times$ longer than broad; lateral margins slightly constricted posteriorly; anterior eye corneate, posterior eye lens low; epistome triangular but small; with 18 setae arranged 6: 4: 4: 2: 2 . Chaetotaxy of coxae: $2+3: 3$ : 3: 4: 4; coxae II with 3-4 coxal spines on each side, set in oblique row, each spine with multiple incisions extending to base of spine.

Abdomen: pleural membrane papillostriate. Tergites and sternites undivided; setae uniseriate and acuminate. Tergal chaetotaxy: 4: 4: 4: 7: 9: 10: 9: 9: 9: 2T2T2: 1T2T1: 0.

Dimensions ( $\mathrm{mm}$ ): tritonymph WAM T85184: Body length ca. 0.95. Pedipalps: femur 0.301/0.084, patella $0.163 / 0.094$, chela 0.499/0.106, hand length 0.147, movable finger length 0.333 . Carapace $0.283 / 0.181$.

\section{Remarks}

Paraliochthonius darwini has been collected from two locations in northern Australia, one situated on Berthier Island, Western Australia, and the other in Darwin, Northern Territory. They were found under stones deeply embedded in the beach sand between the low and high tide marks. They began walking quickly on the wet rocks once exposed to light and air, seeking a place to find refuge. One specimen collected in Darwin was found with a small purple collembolan gripped by its chelicerae, which presumably represented a food item. The collembolan is too macerated for identification.

Specimens of Paraliochthonius darwini were utilized in the molecular analysis of Murienne et al. (2008).

\section{Etymology}

The specific epithet honours the great English naturalist Charles Robert Darwin (1809-1882) in honour of the $150^{\text {th }}$ anniversary of the publication of the "The Origin of Species by Means of Natural Selection" (Darwin 1859) and the 200 ${ }^{\text {th }}$ anniversary of his birth. The species is also known from the city of Darwin, which was named for the naturalist by his former shipmate John Wickham.

\section{Paraliochthonius vachoni sp. nov.}

Figures 6, 19-30

\section{Material examined}

\section{Holotype}

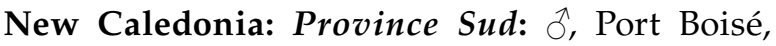
$22^{\circ} 21^{\prime} \mathrm{S}, 166^{\circ} 58^{\prime} \mathrm{E}, 8$ February 1993, under stones on beach, M.S. Harvey, N.I. Platnick, R.J. Raven (MNHN).
Paratypes

New Caledonia: Province Sud: 1 tritonymph, collected with holotype (MNHN).

\section{Diagnosis}

Paraliochthonius vachoni differs from all other species of the genus by the number of setae in the anterior setal row of the carapace, in which there are two pairs of lateral setae slightly anterior to the eyes (Figure 19). In addition, the eyes are large and prominent (Figure 19), and separated by less than the eye diameter.

\section{Description}

\section{Adult (male)}

\section{Colour: uniformly light yellow brown.}

Chelicera: 5 setae on hand, all setae acuminate (Figure 21); movable finger with 1 medial seta; fixed finger with 6 teeth plus a small microdenticle at base, movable finger with 9 teeth; with 2 dorsal and 1 ventral lyrifissures; galea absent; rallum consisting of 7 blades, anterior blade long and finely denticulate, other blades bipinnate; scaly projections present on lateral edges of hand (Figure 21).

Pedipalp: all setae acuminate (Figures 23, 24); trochanter 1.95, femur 4.82, patella 2.11, chela 5.04, hand $1.88 \times$ longer than broad; moveable finger $1.60 \times$ longer than hand, without large basal apodeme. Femur without tactile setae. Patella with three mediodorsal lyrifissures. Fixed chelal finger and hand with 8 trichobothria, movable chelal finger with 4 trichobothria (Figure 25): $i b$ and isb situated close together, sub-medially on dorsum of chelal hand; $e b$, esb and ist forming an oblique row sub-laterally at base of fixed chelal finger; it and est situated sub-distally about 2 areolar diameters apart, it distal to est; et near tip of fixed finger, close to chelal teeth; $x s$ situated distal to $e t$, each seta shorter than those of other trichobothria; 7 microsetae (chemosensory setae) present in longitudinal row on dorsum of chelal hand; trichobothrium st of movable finger situated sub-basally; $s b$ situated slightly closer to $s t$ than to $b$; $b$ and $t$ situated sub-distally, $t$ situated at same level as est. Internal margin of hand with 2 large and 2-3 smaller acuminate spine-like setae, 1 situated at level of $e s b$, the second slightly posterior, and the others, which are smallest, situated medially on hand; inner margin of movable chelal finger with three small spines, largest basally. Single small sensillum situated distal to $s b$ (Figure 26). Venom apparatus absent. Chelal teeth homodentate and diastemodentate (Figure 26): fixed finger with 31 erect, triangular teeth; movable finger with 29 mainly low retrorse teeth; accessory teeth absent. External and internal chelal condyles small and rounded. 


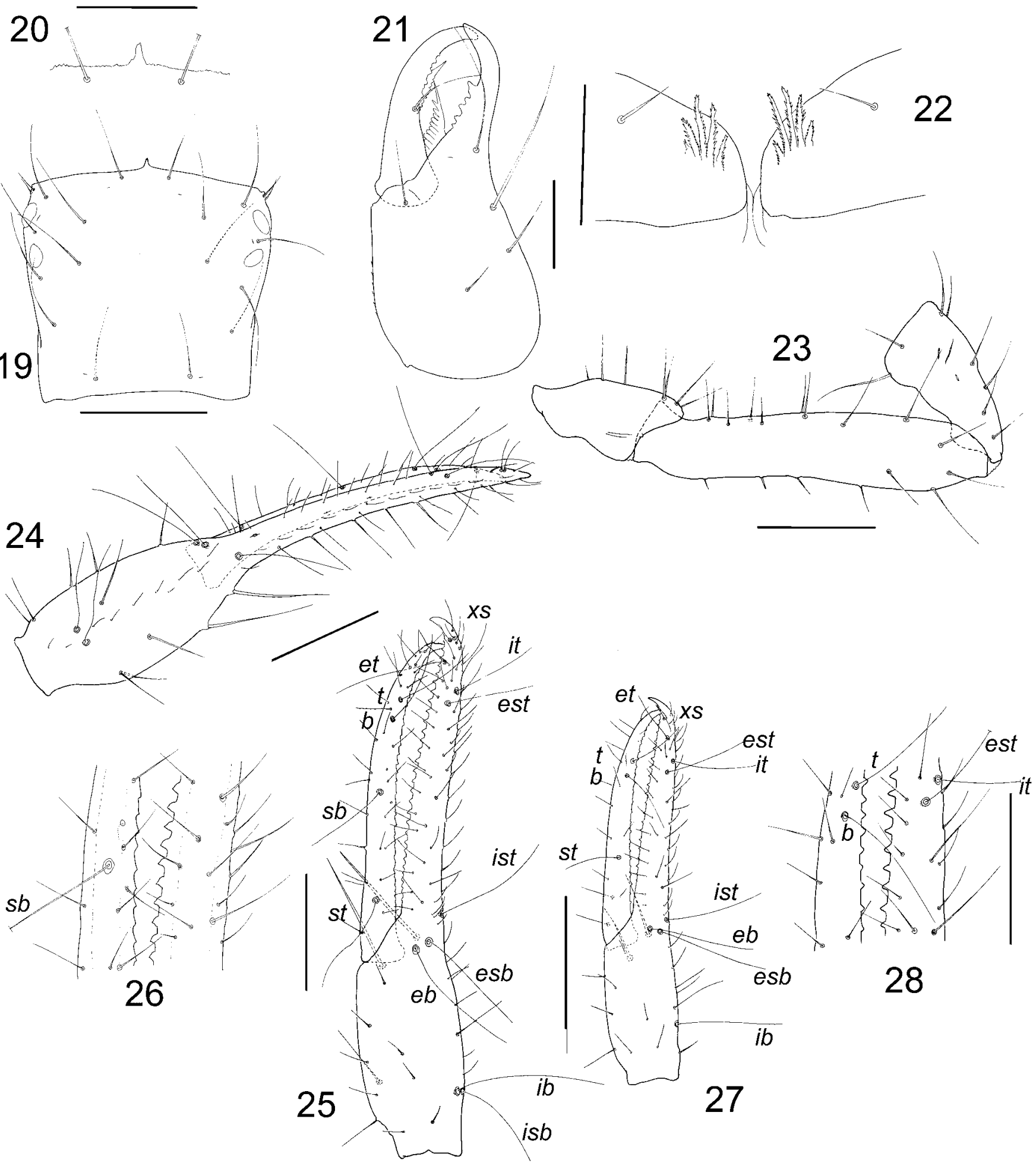

Figures 19-28 Paraliochthonius vachoni sp. nov., holotype male unless stated otherwise: 19, carapace, dorsal aspect; 20 , epistome, dorsal aspect; 21, left chelicera, dorsal aspect; 22, coxae II showing coxal spines, ventral aspect; 23, right pedipalpal trochanter, femur and patella, dorsal aspect; 24, left chela, dorsal aspect; 25, left chela, lateral; 26, detail of chelal fingers, lateral; 27, left chela, lateral, paratype tritonymph; 28, detail of chelal fingers, lateral, paratype tritonymph. Scale lines $=0.1 \mathrm{~mm}(20-22,26,28), 0.2 \mathrm{~mm}$ (Figures 23-25), 0.25 mm (Figures. 19, 27). 
Cephalothorax: carapace $0.88 \times$ longer than broad; lateral margins slightly constricted posteriorly; with four large corneate eyes (Figure 19); triangular epistome present, longer than wide and with small teeth (Figure 20); with 20 setae arranged 8: 4: 4: 2: 2; with very shallow furrow situated near posterior margin; the pre-ocular seta about $50 \%$ length of other setae in anterior row; antero-median seta not situated at base of epistome; with 3 pairs of small lyrifissures, first and second pairs situated in ocular row, third pair situated lateral to setae of posterior row. Chaetotaxy of coxae: 2+3: 3: 3: 5: 5; manducatory process with 2 acuminate distal setae, anterior seta about $2 / 3$ length of medial seta; pedipalpal coxa without dorsal setae; coxae II with 4 coxal spines on right coxa, 5 on left coxa, set in oblique rows (Figure 22), each spine long, with multiple incisions extending to base of spine (Figure 22); intercoxal tubercle absent; without sub-oral seta; coxa I with large, rounded apical projection; setae on coxa I situated near trochanteral foramen.

Abdomen: pleural membrane papillostriate. Tergites and sternites undivided; setae uniseriate and acuminate. Tergal chaetotaxy: 4: 4: 6: 7: 8: 8: 8: 8: 8: 4: T2T: 0. Sternal chaetotaxy: 9: (4) 22 [4+4] (4): (4) 6 (4): 10: 10: 10: 12: 12: 2T1T2: -: 2.

Genitalia: male genitalia with small ejaculatory atrium, lateral apodeme meeting in midline (Figure 30); glandular genital setae in 2 parallel rows of 4 (Figure 30); sternite III with broad V-shaped opening, extending to posterior margin of sternite (Figure 29).

Legs: femora I and II longer than patellae I and II; femora I and II with 1 small transverse lyrifissure situated sub-distally; femur + patella of leg IV 2.92 $x$ longer than broad; tibiae III and IV with 1 medial tactile seta; metatarsi III and IV with 2 seta longer than others; heterotarsate; subterminal tarsal setae not distally serrate; arolium same length as claws, not divided; claws simple.

Dimensions (mm): male holotype (MNHN): Body length 1.62. Pedipalps: trochanter 0.250/0.128, femur $0.602 / 0.125$, patella $0.291 / 0.138$, chela $0.907 / 0.180$, hand length 0.339 , movable finger length 0.544 . Chelicera 0.458/0.207, movable finger length 0.243. Carapace 0.429/0.486. Anterior eye diameter 0.506 , posterior eye diameter 0.464 . Leg I: femur $0.355 / 0.070$, patella $0.180 / 0.065$, tibia $0.179 / 0.054$, tarsus 0.347/0.045. Leg IV: femur + patella $0.589 / 0.202$, tibia $0.397 / 0.086$, metatarsus $0.140 / 0.067$, tarsus $0.397 / 0.034$.

\section{Tritonymph}

Colour: generally pale brown and yellow, chelicera slightly darker.
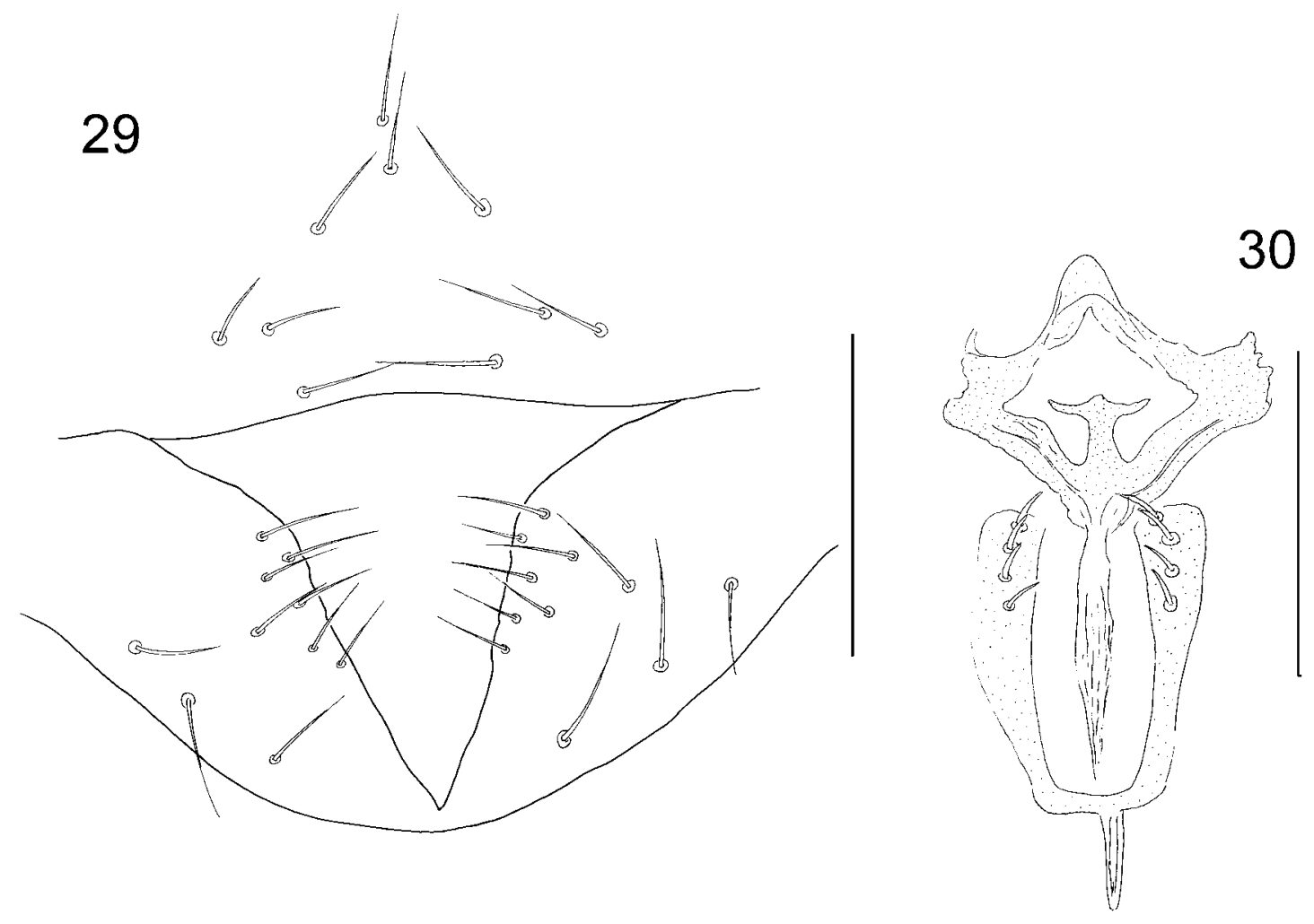

Figures 29-30 Paraliochthonius vachoni sp. nov., holotype male: 29, sternites II and III, ventral aspect; 30, genitalia, ventral aspect. Scale lines $=0.1 \mathrm{~mm}$. 
Chelicera: 5 setae on hand, all setae acuminate; movable finger with 1 medial seta; galea absent.

Pedipalp: femur 4.41, patella 2.03, chela 5.33, hand $1.78 \times$ longer than broad; moveable finger $1.88 \mathrm{x}$ longer than hand, without large basal apodeme. Fixed chelal finger and hand with 7 trichobothria, movable chelal finger with 3 trichobothria (Figure 27): is $b$ and $s b$ absent, ib situated sub-medially on dorso-lateral section of chelal hand; $e b, e s b$ and ist situated close together in an oblique row, sub-laterally at base of chelal fingers; it situated slightly distal to est, about one areolar diameter apart; et situated basal to $x_{S}$, close to chelal teeth; $x$ s situated sub-distally, each seta shorter than those of other trichobothria; a row of microsetae (chemosensory setae) present on dorsum of chelal hand; trichobothrium st of movable finger situated sub-basally; $b$ situated sub-distally near $t$, ca. 4 areolar diameters apart; $t$ at level of it. Hand with 2 large, medial acuminate spine-like setae. Venom apparatus absent. Chelal teeth mainly homodentate, and always diastemodentate (Figure 28): fixed finger with 19 large, well-spaced, erect teeth, plus several small denticles basally; movable finger with 20 well-spaced, retrorse teeth; accessory teeth absent.

Cephalothorax: carapace $0.87 \times$ longer than broad; lateral margins slightly constricted posteriorly; with 2 large eyes; epistome triangular; with 20 setae arranged 8: 4: 4: 2: 2 . Chaetotaxy of coxae: $2+3: 3: 3$ : 4: 4; coxae II with 4 coxal spines on each side, set in oblique row, each spine with multiple incisions extending to base of spine.

Abdomen: pleural membrane papillostriate. Tergites and sternites undivided; setae uniseriate and acuminate. Tergal chaetotaxy: 4: 4: 5: 7: 7: 8: 8: 8: 8: 4: T2T: 0 .

Dimensions ( $\mathrm{mm})$ : tritonymph paratype: Body length ca. 1.18. Pedipalps: femur 0.397/0.090, patella 0. 211/0.104, chela 0.613/0.115, hand length 0.205 , movable finger length 0.385 . Chelicera length $0.339 / 0.162$; movable finger 0.192. Carapace $0.329 / 0.378$.

\section{Remarks}

The two specimens of Paraliochthonius vachoni described here were collected under a rock on the beach at Port Boisé, situated near the southern tip of New Caledonia. It appears to be most similar to P. johnstoni from western Mexico, and P. takashimai from Japan, as all three species have two pairs of eyes, two enlarged, thickened, anteriorly directed setae on the internal margin of the chelal hand, chela less than $0.95 \mathrm{~mm}$ in length and movable chelal finger length less than $0.75 \mathrm{~mm}$, and the chelal fingers with fewer than $31(\hat{0},+$ ) teeth on the fixed finger and fewer than $30(\hat{\sigma},+)$ teeth on the movable finger. It is larger than $P$. johnstoni [e.g. chela $0.91\left({ }^{\Uparrow}\right) \mathrm{mm}$ in length, versus $0.58-0.76$ (ㅇ) $\mathrm{mm}]$, the teeth of the movable chelal finger are low and retrorse (versus erect and triangular in $P$. johnstoni), and the anterior setal row of carapace has eight setae, including two pairs of anteriorlateral setae, rather than just six setae in P. johnstoni. The cheliceral palm of most tyrannochthoniine pseudoscorpions bears five setae, but Morikawa (1958) reported just four setae, and reaffirmed this number of setae in a letter to Dr J.C. Chamberlin (see Chamberlin 1962). It is highly unlikely that this setal number is correct, and that Dr Morikawa may have misinterpreted the setal pattern (Dr M. Judson, in litt.). If this is the case, then Couplet 12 of the key presented in this paper may not work properly. A more detailed description of $P$. takashimai is required to establish how it differs from other species of the genus.

\section{Etymology}

The specific epithet honours Professor Max Vachon (1908-1991) for his outstanding contributions to the study of arachnids, including significant studies on the genus Paraliochthonius (Vachon 1960, 1961).

\section{ACKNOWLEDGEMENTS}

I am very grateful to Jenni Webber for access to the first specimens collected in Darwin, and to Julianne Waldock and Karen Edward for collecting the first specimens in Western Australia. Norman Platnick (American Museum of Natural History, New York) and Robert Raven (Queensland Museum, Brisbane) kindly facilitated the field work in New Caledonia during which Paraliochthonius vachoni was collected. I also wish to thank Norman Platnick and Lorenzo Prendini (American Museum of Natural History, New York), and Charles Griswold and Darrel Ubick (California Academy of Sciences, San Francisco) for access to specimens during visits to their institutions. Mark Judson and Robert Raven very kindly provided comments on a draft of the manuscript.

\section{REFERENCES}

Beier, M. (1939). Die Höhlenpseudoscorpione der Balkanhalbinsel. Studien aus dem Gebiete der Allgemeinen Karstforschung, der Wissenschaftlichen Höhlenkunde, der Eiszeitforschung und den Nachbargebieten 4(10): 1-83.

Beier, M. (1956). Ein neuer Blothrus (Pseudoscorp.) aus Sardinien, und ueber zwei Pseudoscorpione des westmediterranen Litorals. Fragmenta Entomologica 2: 55-63.

Beier, M. (1963). Ordnung Pseudoscorpionidea (Afterskorpione) (pp.). In: Bestimmungsbücher zur Bodenfauna Europas, vol. 1. Akademie-Verlag: Berlin.

Beier, M. (1964). Pseudoscorpione von Neu-Caledonien. 
Pacific Insects 6: 403-411.

Beier, M. (1965). Die Pseudoscorpioniden Neu-Guineas und der benachbarten Inseln. Pacific Insects 7: 749-796.

Beier, M. (1966). Zur Kenntnis der PseudoscorpionidenFauna Neu-Seelands. Pacific Insects 8: 363-379.

Beier, M. (1967a). Some Pseudoscorpionidea from Australia, chiefly from caves. Australian Zoologist 14: 199-205.

Beier, M. (1967b). Contributions to the knowledge of the Pseudoscorpionidea from New Zealand. Records of the Dominion Museum 5: 277-303.

Beier, M. (1967c). Pseudoskorpione aus dem tropischen Ostafrika (Kenya, Tansania, Uganda, etc.). Annalen des Naturhistorischen Museums in Wien 70: 73-93.

Beier, M. (1969). Neue Pseudoskorpione aus Australien. Annalen des Naturhistorischen Museums in Wien 73: 171-187.

Beier, M. (1974a). Ein neuer Paraliochthonius aus Guatemala. Revue Suisse de Zoologie 81: 101-102.

Beier, M. (1974b). Pseudoscorpione aus Südindien des Naturhistorischen Museums in Genf. Revue Suisse de Zoologie 81: 999-1017.

Beier, M. (1976). The pseudoscorpions of New Zealand, Norfolk and Lord Howe. New Zealand Journal of Zoology 3: 199-246.

Beier, M. (1977). Pseudoscorpiones. In: La faune terrestre de l'île de Sainte-Hélène IV. Annales du Musée Royal de l'Afrique Centrale, Zoologie (8) 220: 2-11.

Brown, R.W. (1956). Composition of scientific words, revised edition. Smithsonian Institution Press: Washington, D.C.

Carabajal Márquez, E., García Carrillo, J. and Rodríguez Fernández, F. (2001). Nuevos pseudoscorpiones cavernícolas de la Sierra de Gádor (Almería, España) (Arachnida, Pseudoscorpionida, Chthoniidae). Revista Ibérica de Aracnología 3: 7-15.

Chamberlin, J.C. (1923). New and little known pseudoscorpions, principally from the islands and adjacent shores of the Gulf of California. Proceedings of the California Academy of Sciences (4) 12: 353-387.

Chamberlin, J.C. (1929). On some false scorpions of the suborder Heterosphyronida (Arachnida Chelonethida). Canadian Entomologist 61: 152-155.

Chamberlin, J.C. (1931). The arachnid order Chelonethida. Stanford University Publications, Biological Sciences 7(1): 1-284.

Chamberlin, J.C. (1962). New and little-known false scorpions, principally from caves, belonging to the families Chthoniidae and Neobisiidae (Arachnida, Chelonethida). Bulletin of the American Museum of Natural History 123: 303-352.

Darwin, C. (1859). The origin of species by means of natural selection. Murray: London.

Edward, K.L. and Harvey, M.S. (2008). Short-range endemism in hypogean environments: the pseudoscorpion genera Tyrannochthonius and Lagynochthonius (Pseudoscorpiones: Chthoniidae) in the semiarid zone of Western Australia. Invertebrate Systematics 22: 259-293.

Gabbutt, P.D. (1962). 'Nests' of the marine false-scorpion. Nature 196: 87-88.
Gabbutt, P.D. (1965). The external morphology of two pseudoscorpions Neobisium carpenteri and Neobisium maritimum. Proceedings of the Zoological Society of London 145: 359-386.

Gabbutt, P.D. (1966). An investigation of the silken chambers of the marine pseudoscorpion Neobisium maritimum. Journal of Zoology, London 149: 337-343.

Gardini, G. (1994). I generi Paraliochthonius Beier, 1956 e Spelyngochthonius Beier, 1955 in Italia (Pseudoscorpionida, Chthoniidae). Fragmenta Entomologica 26: 1-10.

Hadži, J. (1933). Prinos poznavanju pseudoskorpijske faune Primorja. Prirodoslovna Istraživanja Kraljevine Jugoslavije 18: 125-192.

Harvey, M.S. (1984). The genus Nannochelifer Beier, with a new species from the Coral Sea (Pseudoscorpionida, Cheliferidae). Journal of Arachnology 12: 291-296.

Harvey, M.S. (1988). Pseudoscorpions from the Krakatau Islands and adjacent regions, Indonesia (Chelicerata: Pseudoscorpionida). Memoirs of the Museum of Victoria 49: 309-353.

Harvey, M.S. (1989). Two new cavernicolous chthoniids from Australia, with notes on the generic placement of the south-western Pacific species attributed to the genera Paraliochthonius Beier and Morikawia Chamberlin (Pseudoscorpionida: Chthoniidae). Bulletin of the British Arachnological Society 8: 21-29.

Harvey, M.S. (1991a). Catalogue of the Pseudoscorpionida. Manchester University Press: Manchester.

Harvey, M.S. (1991b). Notes on the genera Parahya Beier and Stenohya Beier (Pseudoscorpionida: Neobisiidae). Bulletin of the British Arachnological Society 8: 288-292.

Harvey, M.S. (1992). The phylogeny and classification of the Pseudoscorpionida (Chelicerata: Arachnida). Invertebrate Taxonomy 6: 1373-1435.

Harvey, M.S. (2009). Pseudoscorpions of the World, version 1.2. Western Australian Museum, Perth. http: / / www.museum.wa.gov.au / arachnids / pseudoscorpions / (accessed March 2009).

Harvey, M.S., Waldock, J.M., Teale, R.J. and Webber, J. (2007). New distribution records of the intertidal pseudoscorpion Parahya submersa (Pseudoscorpiones: Parahyidae). Records of the Western Australian Museum 23: 393-395.

Helversen, O. von (1968). Troglochthonius doratodactylus n. sp., ein troglobionter Chthoniide (Arachnida: Pseudoscorpiones: Chthoniidae). Senckenbergiana Biologica 49: 59-65.

Hoff, C.C. (1963). The pseudoscorpions of Jamaica. Part 2. The genera Pseudochthonius, Paraliochthonius, Lechytia, and Tridenchthonius. Bulletin of the Institute of Jamaica, Science Series 10(2): 1-35.

Judson, M.L.I. (2007). A new and endangered species of the pseudoscorpion genus Lagynochthonius from a cave in Vietnam, with notes on chelal morphology and the composition of the Tyrannochthoniini (Arachnida, Chelonethi, Chthoniidae). Zootaxa 1627: 53-68.

Lee, V.F. (1979). The maritime pseudoscorpions of Baja California, México (Arachnida: Pseudoscorpionida). Occasional Papers of the California Academy of Sciences 131: i-iv, 1-38. 
Mahnert, V. (1986). Die Pseudoskorpione (Arachnida) Kenyas. VIII. Chthoniidae. Revue Suisse de Zoologie 92: 823-843.

Mahnert, V. and Schuster, R. (1981). Pachyolpium atlanticum n. sp., ein Pseudoskorpion aus der Gezeitenzone der Bermudas - Morphologie und Ökologie (Pseudoscorpiones: Olpiidae). Revue Suisse de Zoologie 88: 265-273.

Menozzi, C. (1924). Nuova specie di Pseudoscorpione alofilo. Annuario del Museo Zoologico della R. Università di Napoli 5: 1-3.

Morikawa, K. (1955). [On a new Garypidae (Pseudoscorp.) from Japan]. Zoological Magazine, Tokyo 64: 225-228.

Morikawa, K. (1958). Maritime pseudoscorpions from Japan. Memoirs of Ehime University (2B) 3: 5-11.

Muchmore, W.B. (1967). Two new species of the pseudoscorpion genus Paraliochthonius. Entomological News 78: 155-162.

Muchmore, W.B. (1972). The pseudoscorpion genus Paraliochthonius (Arachnida, Pseudoscorpionida, Chthoniidae). Entomological News 83: 248-256.

Muchmore, W.B. (1973). A new genus of pseudoscorpions based upon Atemnus hirsutus (Pseudoscorpionida: Chernetidae). Pan-Pacific Entomologist 49: 43-48.

Muchmore, W.B. (1974). Pseudoscorpions from Florida. 3. Epactiochernes, a new genus based upon Chelanops tumidus Banks (Chernetidae). Florida Entomologist 57: 397-407.

Muchmore, W.B. (1982). The genus Anagarypus (Pseudoscorpionida: Garypidae). Pacific Insects 24: 159-163.

Muchmore, W.B. (1984a). Further data on Mucrochernes hirsutus (Banks) (Pseudoscorpionida, Chernetidae). Pan-Pacific Entomologist 60: 20-22.

Muchmore, W.B. (1984b). Pseudo-scorpions from Florida and the Caribbean area. 13. New species of Tyrannochthonius and Paraliochthonius from the Bahamas, with discussion of the genera (Chthoniidae). Florida Entomologist 67: 119-126.

Muchmore, W.B. (2000). The Pseudoscorpionida of Hawaii Part I. Introduction and Chthonioidea. Proceedings of the Entomological Society of Hawaii 34: 147-162.

Muchmore, W.B. and Alteri, C.H. (1969). Parachernes (Arachnida, Chelonethida, Chernetidae) from the coast of North Carolina. Entomological News 80: 131-137.

Murienne, J., Harvey, M.S. and Giribet, G. (2008). First molecular phylogeny of the major clades of Pseudoscorpiones (Arthropoda: Chelicerata). Molecular Phylogenetics and Evolution 49: 170-184.

Murthy, V.A. and Ananthakrishnan, T.N. (1977). Indian Chelonethi. Oriental Insects Monograph 4: 1-210.

Schulte, G. (1976). Litoralzonierung von Pseudoskorpionen an der nordamerikanischen Pazifikküste (Arachnida: Pseudoscorpiones: Neobisiidae, Garypidae). Entomologica Germanica 3: 119-124.

Vachon, M. (1960). Sur une nouvelle espèce halophile de Pseudoscorpions de l'Archipel de Madère: Paraliochthonius hoestlandti (Fam. des Chthoniidae). Bulletin du Muséum National d'Histoire Naturelle, Paris (2) 32: 331-337.

Vachon, M. (1961). Remarques sur les Pseudoscorpions de Madère, des Açores et les Canaries (première note). Bulletin du Muséum National d'Histoire Naturelle, Paris (2) 33: 98-104.

Wagenaar-Hummelinck, P. (1948). Studies on the fauna of Curaçao, Aruba, Bonaire and the Venezuelan Islands: no. 13. Pseudoscorpions of the genera Garypus, Pseudochthonius, Tyrannochthonius and Pachychitra. Natuurwetenschappelijke Studiekring voor Suriname en Curaçao 5: 29-77.

Manuscript received 27 April 2009; accepted 9 July 2009. 